OPEN ACCESS

Edited by: Luisa De Risio,

Animal Health Trust, United Kingdom

Reviewed by:

Richard Malik,

University of Sydney, Australia

Thomas Robert Harcourt-Brown, University of Bristol, United Kingdom

*Correspondence: Andrea Fischer andreafischer@/mu.de; andrea.fischer@

med.vetmed.uni-muenchen.de

Specialty section:

This article was submitted to Veterinary Neurology and Neurosurgery,

a section of the journal

Frontiers in Veterinary Science

Received: 04 February 2019 Accepted: 30 April 2019

Published: 31 May 2019

Citation:

Buhmann G, Paul F, Herbst W, Melzer F, Wolf G, Hartmann $K$ and Fischer A (2019) Canine Brucellosis:

Insights Into the Epidemiologic Situation in Europe.

Front. Vet. Sci. 6:151 doi: 10.3389/fvets.2019.00151

\section{Canine Brucellosis: Insights Into the Epidemiologic Situation in Europe}

\author{
Gesine Buhmann ${ }^{1}$, Frauke Paul ${ }^{2}$, Werner Herbst ${ }^{3}$, Falk Melzer ${ }^{4}$, Georg Wolf ${ }^{5}$, \\ Katrin Hartmann ${ }^{1}$ and Andrea Fischer ${ }^{1 *}$ \\ ${ }^{1}$ Clinic of Small Animal Medicine, Centre for Clinical Veterinary Medicine, LMU Munich, Munich, Germany, ${ }^{2}$ IDEXX \\ Laboratories, Ludwigsburg, Germany, ${ }^{3}$ Department of Veterinary Medicine, Institute of Hygiene and Infectious Diseases of \\ Animals, University of Giessen, Gießen, Germany, ${ }^{4}$ Institute of Bacteriological Infections and Zoonosis, \\ Friedrich-Loeffler-Institute, Federal Research Institute for Animal Health, Jena, Germany, ${ }^{5}$ Department of Veterinary Science, \\ Institute for Infectious Diseases and Zoonoses, LMU Munich, Munich, Germany
}

Brucella canis is one of many responsible pathogens of discospondylitis in dogs and infections require specific management. Little is known about the epidemiologic situation in Europe. The purpose of the study was to get insights into the occurrence of brucellosis in dogs in Europe. The database of a European veterinary laboratory was screened for Brucella positive samples. Additionally, medical records of a veterinary hospital in Germany were screened for diagnosis of discospondylitis and brucellosis. The laboratory received samples from 20 European countries for Brucella testing in dogs: $3.7 \%$ of submitted samples were Brucella spp. PCR-positive $(61 / 1,657)$, and Brucella canis antibodies were identified in 5.4\% of submitted samples $(150 / 2,764)$. Brucella spp. PCR-positive samples originated from Spain (11.1\% of submitted samples), Poland (6.7\% of submitted samples) and rarely from Italy and France. Samples with Brucella canis antibodies originated from 13 European countries (Sweden, Belgium, Austria, Switzerland, Italy, Finland, Germany, Denmark, Hungary, Norway, Poland, France, Netherlands). Young dogs (0-24 months) had a 5.4-fold increased risk of PCR positive samples. The supplementary medical records search identified four young female dogs (7-30 months) with Brucella canis discospondylitis in Germany. The four dogs had been imported to Germany from Eastern European countries (Moldavia, Romania, Macedonia). In conclusion, infection with Brucella canis needs to be considered in dogs in Europe and diagnostics for Brucella canis infection appear indicated in young dogs with discospondylitis.

Keywords: Canine brucellosis, Brucella canis, zoonosis, epidemiology, dog, European countries, discospondylitis

\section{INTRODUCTION}

Veterinary neurologists are frequently confronted with spinal pain in dogs. One differential diagnosis of spinal pain is discospondylitis. The most common etiologies of discospondylitis in dogs are Staphylococcus species, and less frequently Streptococcus species, Escherichia coli, Aspergillus species and Brucella canis or Brucella suis, as well. Routine diagnosis relies on spinal radiographs, CT or MRI, blood cultures and needle aspirates of effected disc spaces using fluoroscopy or CT. A special approach is required for diagnosis of Brucella discospondylitis (1-3).

Brucella canis (B. canis) is a gram-negative, facultative intracellular coccobacillus which has been reported in many regions of the world and is considered endemic in Southern USA, in Central and South America and in Mexico (4-8). B. canis also occurs in Canada (9). Frequent reports 
of infections with $B$. canis also originate from Asia (China, Japan, India) and Africa (Nigeria, Zimbabwe) (5, 10-13). It is exotic in Australia and does not occur in New Zealand (1416). In Germany, B. canis was reported in 1976 in a colony of Beagle dogs (17) and 2003 in one male dog with epididymitis and orchitis (18). Rare cases originate also from other European countries, such as Sweden $(19,20)$, the United Kingdom (21, 22), Austria (23), Italy (24), and Hungary (25). It is generally assumed that countries with a large stray dog population have a higher prevalence of infection, since stray dogs can contribute to distribution and retention of this organism in dog populations (6, 13, 26, 27). Complementary, breeding colonies are at increased risk of maintaining the infection, as well (28).

$B$. canis discospondylitis is the most frequently reported manifestation outside the genital tract $(24,29-33)$, others are generalized lymphadenopathy (19), intraocular inflammation $(34,35)$, and rarely osteomyelitis (36) and meningoencephalitis (37) with similar appearance as neurobrucellosis in humans (38). Common consequences of $B$. canis infection in dogs are late abortion, stillbirth, and failure to conceive in female dogs $(8,19,39,40)$ and epididymitis, orchitis, prostatitis and infertility in male dogs $(24,29,41)$. Puppies can be born, which have very high risk of perinatal mortality (37). A major concern is that $B$. canis can cause a lifelong infection with intermittent shedding of bacteria $(42,43)$. Awareness of canine brucellosis as a zoonosis increased in the last years $(7,44,45)$, although symptomatic human infections are considered rare (46). Transmission of $B$. canis from dogs to humans is possible. Immunocompromized people with close contact to infected dogs $(44,47,48)$, and laboratory workers handling infected specimen are considered at risk for infection $(46,49-51)$. Yet, surveillance for brucellosis as a zoonotic disease commonly focuses on $B$. melitensis, $B$. suis and $B$. abortus (52-54). Less attention has been paid to $B$. canis in Europe, although dogs usually live in close contact with their owners.

The purpose of the study was to get insights into the occurrence of Brucella canis in dogs in Europe.

We screened the database of a European laboratory for Brucella positive samples. Additionally, medical records of a German veterinary hospital were reviewed for dogs with Brucella canis discospondylitis and their geographic origin.

\section{MATERIALS AND METHODS}

The database of a veterinary diagnostic laboratory (IDEXX laboratories, Ludwigsburg, Germany), which received samples from dogs for $B$. canis testing from 20 European countries, was investigated (2011-2016). The laboratory had received 4,421 samples from dogs for testing for Brucella infection: 1,657 samples were submitted for detection of Brucella spp. with polymerase chain reaction (PCR), and 2,764 samples were submitted for detection of $B$. canis antibodies. Four samples were marked as originating from the same two dogs (Supplementary Tables 1-3). Samples were submitted by veterinarians or dog breeders. Polymerase chain reaction was a real-time PCR (IDEXX RealPCR ${ }^{\mathrm{TM}}$ ), which amplified the 76 bp-sequence of the internal transcribed spacer gene region of
Brucella spp. The IDEXX RealPCR ${ }^{\mathrm{TM}}$ detects $B$. canis, $B$. microti, B. melitensis, B. abortus, B. suis, and B. ovis. Sequencing was not performed. Antibody test was routinely performed with an agglutination test (Institute of Hygiene and Infectious Diseases of Animals, JLU Gießen, Gießen, Germany). B. canis strain RM $6 / 66$ was used as antigen. After growth on tryptone soy bean agar plates in a $5 \% \mathrm{CO}_{2}$ enriched atmosphere for $48 \mathrm{~h}$ at $37^{\circ} \mathrm{C}$ bacteria were harvested and suspended in $0.15 \mathrm{M}$ phosphate buffered saline (PBS) ( $\mathrm{pH}$ 7.2). The suspension was filtered through four layers of gauze and subsequently heated in a water bath at $56^{\circ} \mathrm{C}$ for $90 \mathrm{~min}$ to inactivate the microorganism. After washing the bacteria twice in PBS the last pellet was suspended in the same buffer to an about 10-fold higher concentration as required for the agglutination test. As a preservative Merthiolate was added (final concentration of $0.01 \%$ ). For the agglutination test the concentrated antigen was diluted in $0.15 \mathrm{M} \mathrm{NaCl}$ giving a turbidity of McFarland no. 5. Each dilution $(0.5 \mathrm{ml})$ of a $\log 2$ dilution series in $0.15 \mathrm{M} \mathrm{NaCl}$, beginning with $1: 25$, of the field sera was mixed with the same volume of the antigen suspension giving a final serum dilution of 1:50, and then incubated for $48 \mathrm{~h}$ at $37^{\circ} \mathrm{C}$ in a humidified atmosphere. The reciprocal value of the last dilution which still revealed an at least $50 \%$ agglutination of the B. canis cells was recorded as titer. For controls known negative (field serum) and positive dog sera were used. The latter was from a dog experimentally infected with B. canis. According to Carmichael and Greene a titer of 100 was chosen as cut off value $(43,55,56)$.

The following data were retrieved from the laboratory database: Submitted materials for diagnostic testing for $B$. canis infection, requested diagnostic tests (B. canis antibodies, Brucella spp. PCR), diagnostic test results for $B$. canis antibodies (presence, absence), diagnostic test results for Brucella spp. PCR (positive, negative), country of origin of the samples, sex, and age of the dogs. Frequency of PCR-positive samples and frequency of samples with $B$. canis antibodies were calculated as percentages of all submitted samples and for each country. Confidence intervals ( $\mathrm{CI}_{95 \%}$; calculation according to Abraham Wald) were calculated in excel (Microsoft Office Standard 2013) with the following formula: $C I_{95 \%}=P \pm 1,96 \sqrt{\frac{P(1-P)}{n}}$ [ $n$ : total number of samples tested; P: proportion of samples with positive test results (\%)]. The strength of association between positive PCR or antibody presence and sex and age was estimated by calculation of odds ratios (ORs). An odds ratio with a 95\% CI excluding 1 was considered to indicate a significant association at the $5 \%$ level.

As a secondary supplementary study, the medical records of a neurology service in a German veterinary hospital were reviewed for dogs with a diagnosis of discospondylitis and Brucella canis infection. Data on diagnostics, traveling history and geographic origin of the dogs were extracted (Supplementary Table 4).

The ethics committee of the veterinary faculty LMU Munich approved the study (114-16-02-2018).

\section{RESULTS}

The European veterinary diagnostic laboratory had received 4,421 samples from 4,419 dogs for testing for canine brucellosis 


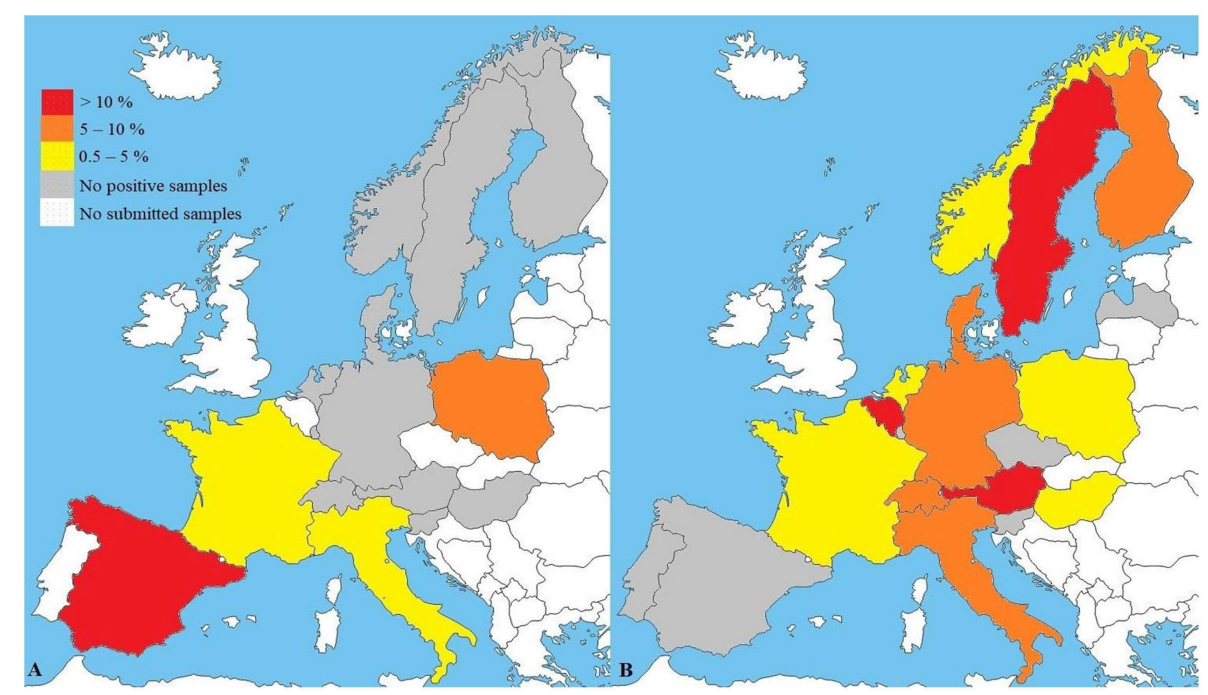

FIGURE 1 | (A) Results of Brucella spp. PCR $(n=1,657)$ and (B) B. canis antibody testing $(n=2,764)$ in a veterinary diagnostic laboratory. Maps reflect preference to use PCR (A) or antibody tests (B) in respective countries. B. suis may not be recognized. Sample sizes and confidence intervals (Cl95\%) for each country are described in Tables 2, 3.

within a 5-year period (Table 1). Samples submitted to the laboratory for Brucella spp. PCR originated from 15 European countries. PCR was positive in $3.7 \%(61 / 1,657)$ of all submitted samples. Brucella spp. PCR-positive samples originated from four European countries: Spain, Poland, Italy and France (Figure 1A). Sample sizes for each country are described in Table 2. Young dogs (0-2 years old) had a 5.4-fold increased risk for being PCR-positive (OR 5.4; $\mathrm{CI}_{95 \%}$ 2.2-13.7) compared to dogs aged 3 years of age or older (OR 0.2 ; $\mathrm{CI}_{95 \%} 0.1-$ $0.5)$. Statistical analysis failed to demonstrate an association between the sex of the dogs and positive Brucella spp. PCR. Samples submitted to the laboratory for B. canis antibody testing originated from 20 European countries. Presence of antibodies was documented in 5.4\% $(150 / 2,764)$ of all submitted samples. Samples with B. canis antibodies originated from 13 European countries: Sweden, Belgium, Austria, Switzerland, Italy, Finland, Germany, Denmark, Hungary, Norway, Poland, France and the Netherlands (Figure 1B). Sample sizes for each country are described in Table 3. Young dogs had a lower risk of being antibody-positive (OR 0.6; $\mathrm{CI}_{95 \%}$ 0.4-0.9). Conversely, an increased risk for $B$. canis antibody positivity was observed in dogs aged 3 years or older (OR 1.6; $\mathrm{CI}_{95 \%}$ 1.1-2.2). Statistical analysis failed to demonstrate an association between the sex of the dogs and the presence of Brucella canis antibodies.

The medical records search identified four dogs with $B$. canis infection and discospondylitis (Figures 2A,B). The four dogs (3 female-spayed, 1 female-intact; age 7-30 months) originated from Eastern European countries (1 Moldavia, 2 Romania, 1 North Macedonia) and had been brought to Germany between one and 23 months prior to presentation. None of the dogs had been used for breeding purposes. Diagnosis of brucellosis was based on growth on bacterial blood cultures and bacteria identification by MALDI-TOF mass spectrometry (3 dogs) or presence of $B$. canis antibodies [ $1 \mathrm{dog}$, tested twice, agglutination test and indirect fluorescent antibody test (IFAT 1:512)]. Two additional multiplex PCR assays (Bruce-ladder and New Bruceladder) confirmed growth of B. canis on blood cultures (3 dogs). Using these methods most of the known Brucella species can be identified by specific band patterns of amplificates of different sizes. It is even possible to differentiate between $B$. suis biovars and B. canis $(57,58)$.

\section{DISCUSSION}

This study provides insights into the regional occurrence of B. canis in dogs in Europe. The evaluation of the European laboratory's database showed that PCR- and antibody-positive samples originated from dogs from a variety of European countries, suggesting the widespread presence of $B$. canis in Europe. Brucella spp. DNA was present in 3.7\% of all submitted samples and B. canis antibodies in $5.4 \%$ of samples submitted for diagnostic testing for canine Brucella infection from 20 European countries. Yet, the true occurrence of B. canis infection in dogs in Europe remains unknown. Data presented here reveal only occurrence in samples in which testing for B. canis was specifically requested by the veterinarian or originate from populations at risk and, thus, are not representative of the exact occurrence in the dog population of the respective country. Limitations of the present study are that the results refer to samples from preselected dogs and do not reflect countrywide occurrence. The samples were collected from a heterogeneous group of dogs, so the proportions of positive tested samples must be interpreted critically and cannot measure a real country prevalence of canine brucellosis. Another limitation in the interpretation of the data is the non-species-specific PCR used by the laboratory. Dogs are susceptible to infections with $B$. 
TABLE 1 | Submitted samples and diagnostic test results for B. canis in the laboratory (2011-2016).

\begin{tabular}{|c|c|c|c|c|}
\hline & \multicolumn{2}{|c|}{ Brucella spp. PCR } & \multicolumn{2}{|c|}{ B. canis antibodies } \\
\hline & $\begin{array}{l}\text { Submitted samples } \\
\qquad(n=1657)\end{array}$ & $\begin{array}{l}\text { Positive samples } \\
\qquad(n=61)\end{array}$ & $\begin{array}{l}\text { Submitted samples } \\
\qquad(n=2764)\end{array}$ & $\begin{array}{c}\text { Positive samples } \\
\left(n=150^{*}\right)\end{array}$ \\
\hline \multicolumn{5}{|l|}{ SEX } \\
\hline Female & 600 & 2 & 938 & 58 \\
\hline Male & 300 & 9 & 1188 & 61 \\
\hline Unknown & 757 & 50 & 636 & 29 \\
\hline \multicolumn{5}{|l|}{ AGE } \\
\hline $0-2$ years & 1085 & 55 & 1449 & 63 \\
\hline $3-5$ years & 383 & 4 & 595 & 45 \\
\hline $6-8$ years & 104 & 0 & 348 & 21 \\
\hline$>8$ years & 27 & 1 & 216 & 12 \\
\hline Unknown & 58 & 1 & 154 & 7 \\
\hline \multicolumn{5}{|l|}{ MATERIAL } \\
\hline Whole blood & 47 & 0 & 279 & 20 \\
\hline Serum & 1 & 1 & 2484 & 130 \\
\hline Urine & 8 & 0 & 0 & 0 \\
\hline feces & 1 & 0 & 0 & 0 \\
\hline Ejaculate & 21 & 0 & 0 & 0 \\
\hline Cerebrospinal fluid & 12 & 0 & 1 & 0 \\
\hline Synovial fluid & 1 & 0 & 0 & 0 \\
\hline Bronchoalveolar lavage & 1 & 0 & 0 & 0 \\
\hline Mucosal swab of genital tract & 70 & 0 & 0 & 0 \\
\hline Mucosal swab of rectum & 1 & 0 & 0 & 0 \\
\hline Unknown swabs/aspirates & 1256 & 56 & 0 & 0 \\
\hline Tissue of testis & 4 & 0 & 0 & 0 \\
\hline Tissue of aborted material & 1 & 0 & 0 & 0 \\
\hline Tissue of skin & 1 & 0 & 0 & 0 \\
\hline Unknown biopsies/tissues & 231 & 4 & 0 & 0 \\
\hline Bone marrow & 1 & 0 & 0 & 0 \\
\hline
\end{tabular}

"150 samples from 148 dogs.

abortus, B. suis and B. melitensis. Infections with other Brucella spp. than B. canis should be considered in countries in which brucellosis is not yet eradicated, if the dog is fed raw pig meat or is a hunting dog or is housed on a farm $(2,16,59)$. In addition, number of samples from several countries was insufficient for estimating an accurate frequency of positivity as reflected by the confidence intervals (Tables 2 and 3). In the present study, the laboratory database only specified the country of origin, but otherwise the precise origin of the samples remained unknown. Furthermore, the diagnosis of $B$. canis infection with antibodies faces several limitations: False positive results can can result from cross-reactions with other bacteria that offer the same antigenic determinants or tests can be negative early during infection in the first 3 to 8 weeks $(39,43,53,60)$. There are no official databases: Canine brucellosis (B. canis) is not notifiable to WHO or EU compared to brucellosis in cattle (B. abortus), pigs (B. suis), sheep and goats ( $B$. melitensis). Furthermore, investigations on B. canis oftentimes are restricted to preselected groups of dogs from kennels with reproductive problems or single incidences of discospondylitis $(20,23,25)$. Support for the findings of the present study comes from a number of recent reports of $B$. canis infection in dogs from several other European countries, such as Sweden $(19,20)$, the United Kingdom (21, 22), Austria (23), Italy (24), Hungary (25) or Switzerland (61).

Bacterial isolation has been considered the only proof of B. canis infection $(39,60,62)$. More recently, PCR of clinical samples has been suggested as a diagnostic test for detection of subclinical and early infections prior to antibody development (63-67). PCR detects Brucella spp. DNA in samples, and positive results indicate infection with Brucella spp. Thus, results of samples from Spain and Poland suggest that B. canis occurs in these countries (20). In samples from Spain, $11.1 \%$ had positive PCR results, and in samples from Poland, $6.7 \%$ showed positive PCR results and $3.7 \%$ revealed the presence of $B$. canis antibodies. So far, there is a lack of reports on B. canis infections in Polish dogs. Iwaniak et al. (68) even stated that B. canis had never been confirmed in Poland (68). Yet, a case report from Sweden in 2012 established a connection between a bitch with $B$. canis infection that aborted repeatedly, and a stud dog from Poland (19). 


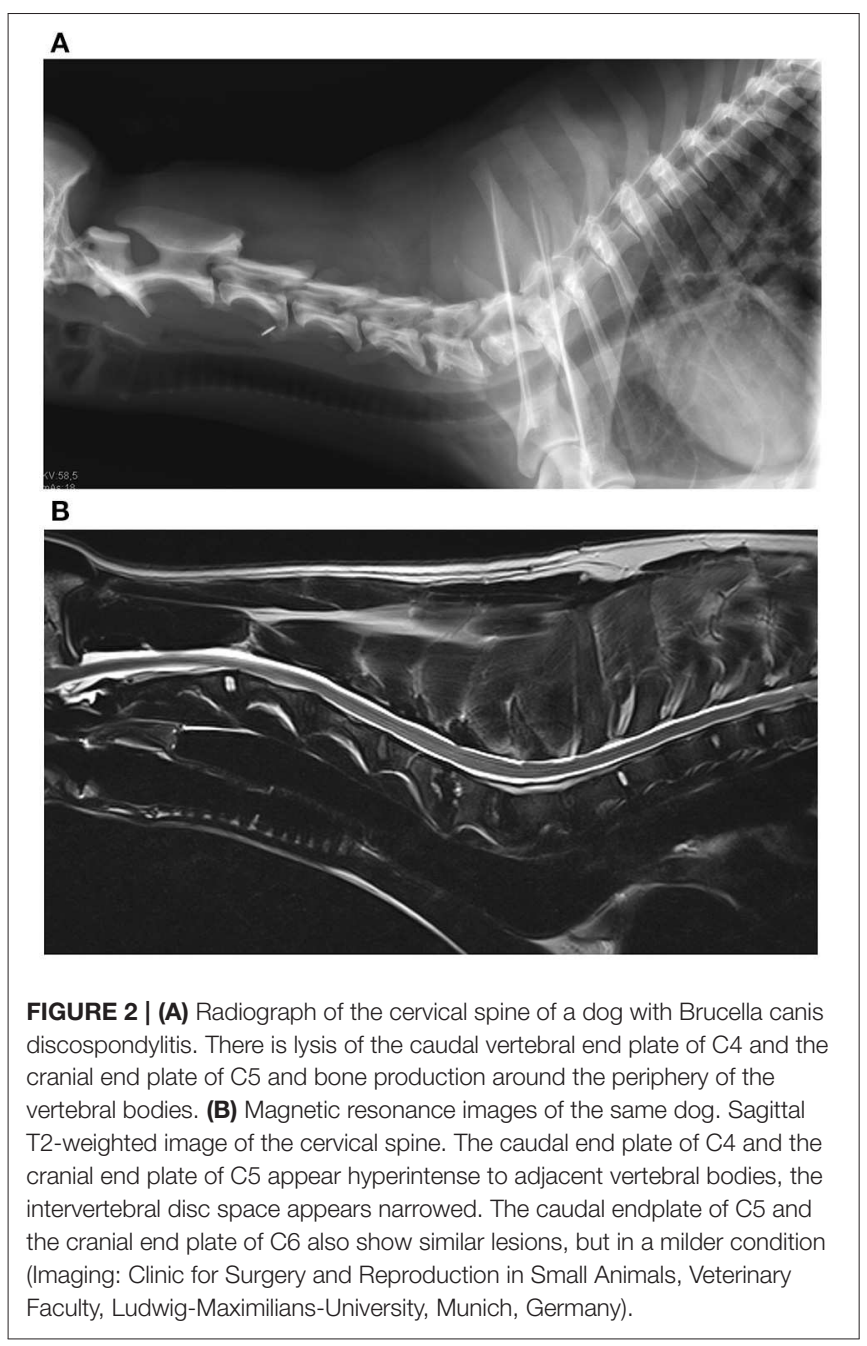

Antibody testing was only available from few Spanish samples, which are not representative, but previously Mateu de Antonia et al. (69) indicated B. canis antibody prevalence for Spanish stray dogs as high as $6.5 \%$ (69). There was also a report on a brucellosis outbreak in a Swedish kennel, in which two diseased bitches had been mated with stud dogs from Spain (20). It may also be of interest that the present study revealed B. canis antibodies in $6.9 \%$ of samples from Finland, which is in contrast to data from Dalhbom et al. (70), who had shown that 388 dogs from 94 Finnish kennels had no B. canis antibodies (70). An important limitation of epidemiologic studies of Brucella canis based on antibodies is the fact that positive samples were not tested twice. In order to exclude false positive results, confirmation with a second serological test would be advantageous. Thus, further investigations are warranted to investigate regional differences in B. canis occurrence. The results of this study have also implications for the diagnosis of discospondylitis. The gold standard for diagnosis of the specific underlying etiology of discospondylitis is bacterial isolation with blood and urine cultures, or in case of negative blood/urine cultures with cultures of image-guided disc biopsies $(1,3)$. However, advantages of PCR
TABLE 2 | Submitted samples for Brucella spp. PCR testing: Country of origin, positivity and confidence intervals $\left(\mathrm{Cl}_{95 \%}\right)$.

\begin{tabular}{lcccc}
\hline $\begin{array}{l}\text { Country } \\
\text { of origin }\end{array}$ & $\begin{array}{c}\text { Submitted } \\
\text { samples }\end{array}$ & $\begin{array}{c}\text { Positive } \\
\text { samples }\end{array}$ & Positive $\%$ & Cl95\% \\
\hline Spain & 253 & 28 & 11.10 & $7.20-14.90 \%$ \\
Poland & 432 & 29 & 6.70 & $4.40-9.10 \%$ \\
Italy & 103 & 1 & 1.00 & $0.00-2.90 \%$ \\
France & 382 & 3 & 0.80 & $0.00-1.70 \%$ \\
Germany & 386 & 0 & 0.00 & - \\
Netherlands & 32 & 0 & 0.00 & - \\
Austria & 35 & 0 & 0.00 & - \\
Hungary & 13 & 0 & 0.00 & - \\
Denmark & 9 & 0 & 0.00 & - \\
Switzerland & 5 & 0 & 0.00 & - \\
Finland & 2 & 0 & 0.00 & - \\
Luxembourg & 2 & 0 & 0.00 & - \\
Sweden & 1 & 0 & 0.00 & - \\
Slovenia & 1 & 0 & 0.00 & - \\
Norway & 1 & 0.00 & 3.70 & - \\
All samples & 1,657 & & $0.60 \%$ \\
\hline & & 0 & 0.00 & - \\
\hline
\end{tabular}

are to detect acute or chronic infections and the possibility to examine blood, urine and secretions. Especially, vaginal swabs or semen are suitable materials for Brucella diagnosis with PCR (63, 71 ). In our study, swabs and aspirates of unknown origin were the most frequently submitted material with positive test results. Combination of different materials for PCR-testing can increase the diagnostic success (71). Consequently, routine testing with PCR from several specimens could enable rapid diagnosis of canine brucellosis in practice and may also be employed for future epidemiologic investigations. The laboratory data shows an increased risk (5.4-fold) of PCR-positive samples in young dogs up to 2 years of age and confirms the overrepresentation of young dogs in previous case reports $(19,22,29,35)$. Another study strengthens this consideration, here, $21 \%$ of 200 canine neonates had a positive B. canis-PCR (72). Adjacent to vertical transmissions between bitches and their puppies via placenta, during parturition or weaning, potential other modes of infection are venereal transmission in sexually mature dogs and infection via mucosal membranes of oropharynx or conjunctiva (urine, vaginal secretions) $(37,73)$. B. canis is well-known to cause abortions and stillbirth in infected bitches. However, puppies can be born and may either die shortly after birth or appear seemingly healthy and develop the disease later $(19,37)$. Thus, chronically infected surviving puppies could present a serious source for harbourage and spread of B. canis (25).

In general, treatment of $B$. canis diseased dogs is controversially discussed because of the risk of harboring this agent lifelong and its zoonotic potential $(19,39)$. Veterinary literature considers treatment of $B$. canis infection in dogs with combined use of tetracyclines and aminoglycosides $(26,29,43)$. WHO guidelines recommend combined treatment with tetracycline or doxycycline and an aminoglycoside antibiotic or rifampicin in humans $(74,75)$. Combination of doxycycline and rifampicin seems to be effective in dogs infected with $B$. suis, as 
TABLE 3 | Submitted samples for B. canis antibody testing: Country of origin, positivity and confidence intervals $\left(\mathrm{Cl}_{95 \%}\right)$.

\begin{tabular}{|c|c|c|c|c|}
\hline $\begin{array}{l}\text { Country } \\
\text { of origin }\end{array}$ & $\begin{array}{l}\text { Submitted } \\
\text { samples }\end{array}$ & $\begin{array}{l}\text { Positive } \\
\text { samples }\end{array}$ & Positive\% & $\mathrm{Cl}_{95 \%}$ \\
\hline Sweden & 22 & 3 & 13.60 & $0.00-28.00 \%$ \\
\hline Belgium & 49 & 6 & 12.20 & $3.10-21.40 \%$ \\
\hline Austria & 95 & 11 & 11.60 & $5.10-18.00 \%$ \\
\hline Switzerland & 85 & 7 & 8.20 & $2.40-14.10 \%$ \\
\hline Italy & 215 & 17 & 7.90 & $4.30-11.50 \%$ \\
\hline Finland & 203 & 14 & 6.90 & $3.40-10.40 \%$ \\
\hline Germany & 1065 & 58 & 5.40 & $4.10-6.80 \%$ \\
\hline Denmark & 117 & 6 & 5.10 & $1.10-9.10 \%$ \\
\hline Hungary & 140 & 6 & 4.30 & $0.90-7.60 \%$ \\
\hline Norway & 73 & 3 & 4.10 & 0.00-8.70\% \\
\hline Poland & 164 & 6 & 3.70 & $0.80-6.50 \%$ \\
\hline France & 415 & 11 & 2.70 & $1.10-4.20 \%$ \\
\hline Netherlands & 98 & 2 & 2.00 & $0.00-4.80 \%$ \\
\hline $\begin{array}{l}\text { Czech } \\
\text { Republic }\end{array}$ & 8 & 0 & 0.00 & - \\
\hline Luxembourg & 5 & 0 & 0.00 & - \\
\hline Malta & 3 & 0 & 0.00 & - \\
\hline Latvia & 3 & 0 & 0.00 & - \\
\hline Spain & 2 & 0 & 0.00 & - \\
\hline Portugal & 1 & 0 & 0.00 & - \\
\hline Slovenia & 1 & 0 & 0.00 & - \\
\hline All samples & 2,764 & 150 & 5.40 & 4.60-6.30\% \\
\hline
\end{tabular}

well (2). Treatment with enrofloxacin eliminated clinical signs and frequent abortions in a kennel with twelve infected breeding dogs (76). A new approach was the additional administration of hydroxychloroquine, which improved clinical signs at an early stage, and reduced treatment failures and relapses in human patients with brucellosis (77). This drug has already been used as an immunomodulatory drug in dogs with lupus erythematosus or lymphoma $(78,79)$. Indeed, no antibiotic therapy appears to eliminate $B$. canis completely from affected dogs, and treatment failures and relapses are frequently reported $(19,26,39)$.

Literature considers the zoonotic potential of $B$. canis is low compared to B. melitensis, B. suis and B. abortus, which are more frequently reported as underlying cause of human brucellosis (52, 80-83). Less attention has been paid to B. canis in Europe, although dogs usually live in close contact with their owners and there is an increasing incidence of dog trafficking and import of puppies from breeding kennels with poor state of health $(19,84)$. An increasing number of case reports describes B. canis infections in people, especially in immunocompromized adults or children $(7,9,47,48,50,51,85-89)$. Clinically conspicuous humans exhibit unspecific signs like undulant fever, fatigue, weakness, lymphadenopathy, liver and spleen enlargement $(7,44,47,49,50,90)$.

In summary, reasons for the occurrence of $B$. canis in Europe could be poor health in selected breeding kennels, the rising international dog trade of breeding animals $(5,19)$ and presence of stray dog populations (6) in some Southern and Eastern European countries (91, 92). Breeding for commercial purposes in very poor housing conditions without veterinary care may constitute additional risks. Import of those puppies could promote transboundary carry-over of $B$. canis infections in dog populations $(84,93-96)$.

\section{CONCLUSION}

In conclusion, infection with Brucella canis needs to be considered in dogs in Europe and diagnostics for Brucella canis infection appear indicated in young dogs with discospondylitis. PCR for rapid diagnosis of Brucella infection may be included in the routine work-up of dogs with discospondylitis.

\section{ETHICS STATEMENT}

The ethics committee of the Faculty of Veterinary Medicine at LMU Munich approved the study (114-16-02-2018).

\section{AUTHOR CONTRIBUTIONS}

$\mathrm{GB}, \mathrm{AF}$, and $\mathrm{KH}$ designed and coordinated the study. FP provided the laboratory data. $\mathrm{GB}, \mathrm{AF}$, and $\mathrm{KH}$ determined the evaluation of the clinical and laboratory data. WH designed the antibody testing. GW designed the microbiological culture of clinical cases. FM designed the PCR examinations of clinical cases. GB, AF, KH, and $\mathrm{WH}$ wrote the manuscript. All authors read and approved the final manuscript.

\section{SUPPLEMENTARY MATERIAL}

The Supplementary Material for this article can be found online at: https://www.frontiersin.org/articles/10.3389/fvets. 2019.00151/full\#supplementary-material

Supplementary Table S1 | Laboratory data: PCR and serology 2014-2016.

Supplementary Table S2 | Laboratory data: PCR 2011-2013.

Supplementary Table S3 | Laboratory data: Serology 2011-2013.

Supplementary Table S4 | Clinical cases - signalement, country of origin and summary of diagnostics and treatments.

\section{REFERENCES}

1. Fischer A, Mahaffey MB, Oliver JE. Fluoroscopically guided percutaneous disk aspiration in 10 dogs with discospondylitis. J Vet Intern Med. (1997) 11:284-7. doi: 10.1111/j.1939-1676.1997.tb00466.x

2. James DR, Golovsky G, Thornton JM, Goodchild L, Havlicek M, Martin P, et al. Clinical management of Brucella suis infection in dogs and implications for public health. Aust Vet J. (2017) 95:19-25. doi: 10.1111/avj.12550

3. Ruoff CM, Kerwin SC, Taylor AR. Diagnostic imaging of discospondylitis. Vet Clin Small Anim. (2018) 48:85-94. doi: 10.1016/j.cvsm.2017.08.007 
4. Flores-Castro R, Suarez F, Ramirez-Pfeiffer C, Carmichael LE. Canine brucellosis: bacteriological and serological investigation of naturally infected dogs in Mexico City. J Clin Microbiol. (1977) 6:591-7.

5. Brower A, Okwumabua O, Massengill C, Muenks Q, Vanderloo P, Duster $\mathrm{M}$, et al. Investigation of the spread of Brucella canis via the U. S. interstate dog trade. Int J Infect Dis. (2007) 11:454-8. doi: 10.1016/j.ijid.2006. 12.009

6. Küster de Paula Dreer M, Dib Gonçalves D, da Silva Caetano IC, Gerônimo E, Menegas PH, Bergo D, et al. Toxoplasmosis, leptospirosis, and brucellosis in stray dogs housed at the shelter in Umuarama municipality, Paraná, Brazil. J Venom Anim Toxins Incl Trop Dis. (2013) 19:23. doi: 10.1186/1678-9199-19-23

7. Krueger WS, Lucero NE, Brower A, Heil GL, Gray GC. Evidence for unapparent Brucella canis infections among adults with occupational exposure to dogs. Zoonoses Public Health. (2014) 61:509-18. doi: 10.1111/zph.12102

8. Keid LB, Chiebao DP, Batinga MCA, Faita T, Diniz JA, Oliveira TMF de S, et al. Brucella canis infection in dogs from commercial breeding kennels in Brazil. Transbound Emerg Dis. (2017) 64:691-7. doi: 10.1111/tbed.12632

9. Cosford KL. Brucella canis: an update on research and clinical management. Can Vet J. (2018) 59:74-81.

10. Cadmus SIB, Adesokan HK, Ajala OO, Odetokun WO, Perrett LL, Stack JA. Seroprevalence of Brucella abortus and B. canis in household dogs in southwestern Nigeria: a preliminary report. J S Afr Vet Assoc. (2011) 82:567. doi: 10.4102/jsava.v82i1.35

11. Chinyoka S, Dhliwayo S, Marabini L, Dutlow K, Matope G, Pfukenyi DM. Serological survey of Brucella canis in dogs in urban Harare and selected rural communities in Zimbabwe. J S Afr Vet Assoc. (2014) 85:1087. doi: 10.4102/jsava.v85i1.1087

12. Di D, Cui B, Wang H, Zhao H, Piao D, Tian L, et al. Genetic polymorphism characteristics of Brucella canis isolated in China. PLoS ONE. (2014) 9:17. doi: 10.1371/journal.pone.0084862

13. Yoak AJ, Reece JF, Gehrt SD, Hamilton IM. Disease control through fertility control: secondary benefits of animal birth control in Indian street dogs. Prev Vet Med. (2014) 113:152-6. doi: 10.1016/j.prevetmed.2013.09.005

14. Rovid Spickler A. Brucellosis: Brucella canis. United States Department of Agriculture Animal and Plant Health Inspection Service (2018). p. 1-10.

15. Gardner D, Reichel M. No evidence of Brucella canis infection in New Zealand dogs. Surveillance. (1997) 24:17-8.

16. Mor SM, Wiethoelter AK, Lee A, Moloney B, James DR, Malik R. Emergence of Brucella suis in dogs in New South Wales, Australia: clinical findings and implications for zoonotic transmission. BMC Vet Res. (2016) 12:19. doi: 10.1186/s12917-016-0835-0

17. Kruedener. Outbreak of a Brucella canis infection in a beagle colony in West Germany. Dev Biol Stand. (1976):251-3.

18. Nöckler K, Kutzer P, Reif S, Rosenberger N, Draeger A, Bahn P, et al. Canine brucellosis-a case report. Berl Munch Tierarztl Wochenschr. (2003) 116:36872.

19. Holst BS, Löfquist K, Ernholm L, Eld K, Cedersmyg M, Hallgren G, et al. The first case of Brucella canis in Sweden: background, case report and recommendations from a northern European perspective. Acta Vet Scand. (2012) 54:18. doi: 10.1186/1751-0147-54-18

20. Kaden R, Ågren J, Båverud V, Hallgren G, Ferrari S, Börjesson J, et al. Brucellosis outbreak in a Swedish kennel in 2013: determination of genetic markers for source tracing. Vet Microbiol. (2014) 174:52330. doi: 10.1016/j.vetmic.2014.10.015

21. Taylor DJ, Peplinksi G, Spence S, Bruce C, Cedersmyg M, Hallgren G, et al. Serological evidence for the presence of Brucella canis infection in dogs in Britain. Vet Rec. (1980) 106:102-4. doi: 10.1136/vr.106.5.102

22. Morgan J, Wake T, Pintos V, Rys H, Grace K, Perret L, et al. Brucella canis in a dog in the UK. Vet Rec. (2017) 180:617. doi: 10.1136/vr.j3004

23. Hofer E, Bagó Z, Revilla-fernández S, Melzer F, Tomaso H, López-goñi I, et al. First detection of Brucella canis infections in a breeding kennel in Austria. New Microbiol. (2012) 35:507-10.

24. Corrente M, Franchini D, Decaro N, Greco G, D’Abramo M, Greco MF, et al. Detection of Brucella canis in a dog in Italy. New Microbiol. (2010) 33:337-41.
25. Gyuranecz M, Szeredi L, Rónai Z, Dénes B, Dencso L, Dán Á, et al. Detection of brucella canis-induced reproductive diseases in a Kennel. J Vet Diagnostic Investig. (2011) 23:143-7. doi: 10.1177/104063871102 300127

26. Reynes E, López G, Ayala SM, Hunter GC, Lucero NE. Monitoring infected dogs after a canine brucellosis outbreak. Comp Immunol Microbiol Infect Dis. (2012) 35:533-7. doi: 10.1016/j.cimid.2012.05.004

27. Brown J, Blue JL, Wooley RE, Dreesen DW. Brucella canis infectivity rates in stray and pet dog populations. Am J Public Health. (1976) 66:88991. doi: 10.2105/AJPH.66.9.889

28. Bramlage DJ, Fortney W, Kesler RM. Best Practices for Brucella canis Prevention and Control in Dog Breeding Facilities. United States Department of Agriculture Animal and Plant Health Inspection Service. (2015)

29. Anderson G, Binnington A. Discospondylitis and orchitis associated with high Brucella titre in a dog. Can Vet J. (1983) 24:249-52.

30. Henderson RA, Hoerlein BF, Kramer TT, Meyer ME. Discospondylitis in three dogs infected with Brucella canis. J Am Vet Med Assoc. (1974) 165:451-5.

31. Kerwin SC, Lewis DD, Hribernik TN, Partington B, Hosgood G, Eilts BE. Diskospondylitis associated with Brucella canis infection in dogs: 14 cases (1980-1991). J Am Vet Med Assoc. (1992) 201:1253-7.

32. Thomas WB. Diskospondylitis and other vertebral infections. Vet Clin North Am Small Anim Pract. (2000) 30:169-82. doi: 10.1016/S0195-5616(00)50008-4

33. Thomas WB. Inflammatory diseases of the central nervous system in dogs. Clin Tech Small Anim Pract. (1998) 13:16778. doi: 10.1016/S1096-2867(98)80038-8

34. Vinayak A, Greene CE, Moore PA, Powell-Johnson G. Clinical resolution of Brucella canis-induced ocular inflammation in a dog. J Am Vet Med Assoc. (2004) 224:1804-7. doi: 10.2460/javma.2004.224.1804

35. Ledbetter EC, Landry MP, Stokol T, Kern TJ, Messick JB. Brucella canis endophthalmitis in 3 dogs: clinical features, diagnosis, and treatment. Vet Ophthalmol. (2009) 12:183-91. doi: 10.1111/j.1463-5224.2009.0 0690.x

36. Smeak DD, Olmstead ML, Hohn RB. Brucella canis osteomyelitis in two dogs with total hip replacements. J Am Vet Med Assoc. (1987) 191:986-90.

37. Carmichael LE, Kenney RM. Canine brucellosis: the clinical disease, pathogenesis, and immune response. J Am Vet Med Assoc. (1970) 156:172634.

38. Algahtani H, Shirah B, Abdulghani D, Farhan R, Algahtani R. Occupational neurobrucellosis mimicking a brain tumor: a case report and review of the literature. Case Rep Infect Dis Hindawi. (2017) 2017:1-5. doi: 10.1155/2017/1434051

39. Wanke MM. Canine brucellosis. Anim Reprod Sci. (2004) 82-3:195207. doi: 10.1016/j.anireprosci.2004.05.005

40. Hollett RB. Canine brucellosis: outbreaks and compliance. Theriogenology. (2006) 66:575-87. doi: 10.1016/j.theriogenology.2006.04.011

41. George L, Carmichael L. Antisperm responses in male dogs with chronic Brucella canis infections. Am J Vet Res. (1984) 45:274-81.

42. Carmichael LE, Zoha SJ, Flores-Castro R. Problems in the serodiagnosis of canine brucellosis: dog responses to cell wall and internal antigens of Brucella canis. Dev Biol Stand. (1984) 56:371-83.

43. Greene CE, Carmichael LE. Canine brucellosis. In: Greene CE, editor. Infectious Diseases of the Dog and Cat. 4th ed. St. Louis, MO: Elservier Saunders (2015). p. 398-410.

44. Lucero NE, Corazza R, Almuzara MN, Reynes E, Escobar GI, Boeri E, et al. Human Brucella canis outbreak linked to infection in dogs. Epidemiol Infect. (2009) 138:280-5. doi: 10.1017/S0950268809990525

45. Sánchez-Jiménez MM, Isaza JP, Alzate JF, Olivera-Angel M. Comparison of Brucella canis genomes isolated from different countries shows multiple variable regions. Genomics. (2015) 106:43-51. doi: 10.1016/j.ygeno.2015.03.004

46. Wallach JC, Giambartolomei GH, Baldi PC, Fossati CA. Human infection with M- strain of Brucella canis. Emerg Infect Dis. (2004) 10:1468. doi: 10.3201/eid1001.020622

47. Lawaczeck E, Toporek J, Cwikla J, Mathison BA. Brucella canis in a HIV-infected patient. Zoonoses Public Health. (2011) 58:150-2. doi: 10.1111/j.1863-2378.2010.01334.x 
48. Lucero NE, Maldonado PL, Kaufman S, Escobar GI, Boeri E, Jacob NR. Brucella canis causing infection in an HIV-infected patient. Vector-Borne Zoonotic Dis. (2010) 10:527-9. doi: 10.1089/vbz.2009.0034

49. Rousseau P. Brucella canis infection in a woman with fever of unknown origin. Postgrad Med. (1985) 78:253-4. doi: 10.1080/00325481.1985.116 99168

50. Lucero NE, Escobar GI, Ayala SM, Jacob N. Diagnosis of human brucellosis caused by Brucella canis. J Med Microbiol. (2005) 54:45761. doi: 10.1099/jmm.0.45927-0

51. Lucero NE, Jacob NO, Ayala SM, Escobar GI, Tuccillo P, Jacques I. Unusual clinical presentation of brucellosis caused by Brucella canis. J Med Microbiol. (2005) 54:505-8. doi: 10.1099/jmm.0.45928-0

52. Galinska EM, Zagórski J. Brucellosis in humans - etiology, diagnostics, clinical forms. Ann Agric Environ Med. (2013) 20:233-8.

53. Banai M, Itin R, Bardenstein S. Perspectives and outcomes of the activity of a reference laboratory for brucellosis. Front Vet Sci. (2018) 4:234. doi: 10.3389/fvets.2017.00234

54. Franc KA, Krecek RC, Häsler BN, Arenas-Gamboa AM. Brucellosis remains a neglected disease in the developing world: a call for interdisciplinary action. BMC Public Health. (2018) 18:125. doi: 10.1186/s12889-017-5016-y

55. Weber A. Untersuchungen zur Mikrobiologischen Diagnose und Epidemiologie der Brucella canis-Infektion des Hundes. Gießen: Habil-Schrift (1976).

56. Weber A, Krauss H. Über die brauchbarkeit des agargel-präzipitationstestes zum nachweis von Brucella canis-infektionen bei beagle-hunden. Berl Munch Tierarztl Wochenschr. (1975) 88:425-7.

57. López-Goñi I, García-Yoldi D, Marín CM, de Miguel MJ, Barquero-Calvo E, Guzmán-Verri C, et al. New Bruce-ladder multiplex PCR assay for the biovar typing of Brucella suis and the discrimination of Brucella suis and Brucella canis. Vet Microbiol. (2011) 154:152-5. doi: 10.1016/j.vetmic.2011.06.035

58. Lopez-Goni I, Garcia-Yoldi D, Marín CM, Miguel MJ, De Munoz PM, Blasco JM, et al. Evaluation of a multiplex PCR assay (Bruce-ladder) for molecular typing of all Brucella species, including the vaccine strains. J Clin Microbiol. (2008) 46:3484-7. doi: 10.1128/JCM.00837-08

59. Forbes LB. Brucella abortus infection in 14 farm dogs. J Am Vet Med Assoc. (1990) 196:911-6.

60. Carmichael LE, Shin SJ. Canine brucellosis: a diagnostician's dilemma. Semin Vet Med Surg. (1996) 11:161-5. doi: 10.1016/S1096-2867(96)80028-4

61. Egloff S, Schneeberger M, Brawand SG, Krudewig C, Schmitt S, Reichler $\mathrm{I}$, et al. Brucella canis infection in a young dog with epididymitis and orchitis. Schweiz Arch Tierheilkd. (2018) 160:743-8. doi: 10.17236/sat 00190

62. Keid LB, Soares RM, Vasconcellos SA, Megid J, Salgado VR, Richtzenhain LJ. Comparison of agar gel immunodiffusion test, rapid slide agglutination test, microbiological culture and PCR for the diagnosis of canine brucellosis. Res Vet Sci. (2009) 86:22-6. doi: 10.1016/j.rvsc.2008. 05.012

63. Keid LB, Soares RM, Vasconcellos SA, Chiebao DP, Megid J, Salgado $\mathrm{VR}$, et al. A polymerase chain reaction for the detection of Brucella canis in semen of naturally infected dogs. Theriogenology. (2007) 67:120310. doi: 10.1016/j.theriogenology.2007.01.003

64. Keid LB, Soares RM, Vieira NR, Megid J, Salgado VR, Vasconcellos SA, et al. Diagnosis of canine brucellosis: comparison between serological and microbiological tests and a PCR based on primers to 16S-23S rDNA interspacer. Vet Res Commun. (2007) 31:951-65. doi: 10.1007/s11259-006-0109-6

65. Kang S-I, Lee S-E, Kim J-Y, Lee K, Kim J-W, Lee H-K, et al. A new Brucella canis species-specific PCR assay for the diagnosis of canine brucellosis. Comp Immunol Microbiol Infect Dis. (2014) 37:23741. doi: 10.1016/j.cimid.2014.07.003

66. Kauffman LK, Bjork JK, Gallup JM, Boggiatto PM, Bellaire BH, Petersen CA. Early detection of Brucella canis via quantitative polymerase chain reaction analysis. Zoonoses Public Health. (2014) 61:48-54. doi: 10.1111/zph.12041

67. Boeri EJ, Wanke MM, Madariaga MJ, Teijeiro ML, Elena SA, Trangoni MD. Comparison of four polymerase chain reaction assays for the detection of Brucella spp. in clinical samples from dogs. Vet World. (2018) 11:2018. doi: 10.14202/vetworld.2018.201-208

68. Iwaniak W, Szulowski K. Brucellosis - the current situation in Poland. Emergent Dis Biosaf. (2015) 1:20-6.
69. Mateu de Antonio EM, Martin M, Casal J. Comparison of serologic tests used in canine brucellosis diagnosis. J Vet Diagn Investig. (1994) 6:2579. doi: 10.1177/104063879400600220

70. Dahlbom M, Johnsson M, Myllys V, Taponen J, Andersson M. Seroprevalence of canine herpesvirus-1 and Brucella canis in Finnish breeding kennels with and without reproductive problems. Reprod Domest Anim. (2009) 131:12831. doi: 10.1111/j.1439-0531.2007.01008.x

71. Keid LB, Soares RM, Vasconcellos SA, Chiebao DP, Salgado VR, Megid J, et al. A polymerase chain reaction for detection of Brucella canis in vaginal swabs of naturally infected bitches. Theriogenology. (2007) 68:126070. doi: 10.1016/j.theriogenology.2007.08.021

72. Souza TD De, Carvalho TF, De Pinto J, Vítor J, Lopes M, Silva MF, et al. Tissue distribution and cell tropism of Brucella canis in naturally infected canine foetuses and neonates. Sci Rep. (2018) 8:7203. doi: 10.1038/s41598-018-25651-x

73. Taques GG II, Barbosa TR, de Martini AC, Pitchenin LC, Braga ÍA, de Melo ALT, et al. Molecular assessment of the transplacental transmission of Toxoplasma gondii, Neospora caninum, Brucella canis and Ehrlichia canis in dogs. Comp Immunol Microbiol Infect Dis. (2016) 49:4750. doi: 10.1016/j.cimid.2016.09.002

74. Corbel M. Brucellosis in Humans and Animals. Geneva: WHO Library Cat Data (2006). p. 1-102.

75. Yousefi-Nooraie R, Mortaz-Hejri S, Mehrani M, Sadeghipour P. Antibiotics for treating human brucellosis. Cochrane Database Syst Rev. (2012) 10:CD007179. doi: 10.1002/14651858.CD007179.pub2

76. Wanke MM, Delpino MV, Baldi PC, Mörtl S, Bacher A, Fossati CA. Use of enrofloxacin in the treatment of canine brucellosis in a dog kennel (clinical trial). Theriogenology. (2006) 66:15738. doi: 10.1016/j.theriogenology.2006.01.034

77. Majzoobi MM, Hashemi SH, Mamani M, Keramat F, Poorolajal J, Ghasemi Basir HR. Effect of hydroxychloroquine on treatment and recurrence of acute brucellosis: a single-blind, randomized clinical trial. Int J Antimicrob Agents. (2018) 51:365-9. doi: 10.1016/j.ijantimicag.2017.08.009

78. Barnard RA, Wittenburg LA, Amaravadi RK, Daniel L, Thorburn A, Thamm DH, et al. Phase I clinical trial and pharmacodynamic evaluation of combination hydroxychloroquine and doxorubicin treatment in pet dogs treated for spontaneously occurring lymphoma Phase I clinical trial and pharmacodynamic evaluation of combination hydroxychloroqu. Landes Biosci. (2014) 10:1415-25. doi: 10.4161/auto.29165

79. Oberkirchner U, Linder KE, Olivry T. Successful treatment of a novel generalized variant of canine discoid lupus erythematosus with oral hydroxychloroquine. Vet Dermatol. (2012) 23:6570. doi: 10.1111/j.1365-3164.2011.00994.x

80. Pelerito A, Cordeiro R, Matos R, Santos MA, Soeiro S, Santos J, et al. Human brucellosis in Portugal-Retrospective analysis of suspected clinical cases of infection from 2009 to 2016. PLOS ONE. (2017) 12:e0179667. doi: 10.1371/journal.pone.0179667

81. Wallach JC, García JL, Cardinali PS, Seijo AP, Benchetrit AG, Echazarreta SE, et al. High incidence of respiratory involvement in a cluster of Brucella suis infected workers from a pork processing plant in Argentina. Zoonoses Public Health. (2017) 64:550-3. doi: 10.1111/zph.12339

82. Shoukat S, Wani H, Ali U, Para PA, Ara S, Ganguly S. Brucellosis: a current review update on zoonosis. J Immunol Immunopathol. (2017) 19:61. doi: 10.5958/0973-9149.2017.00009.0

83. Li M, Zhou X, Li J, Sun L, Chen X, Wang P. Real-time PCR assays for diagnosing brucellar spondylitis using formalin-fixed paraffinembedded tissues. Medicine. (2018) 97:1-5. doi: 10.1097/MD.00000000000 10062

84. Yeates J, Bowles D. Breeding and selling of companion animals. In: Maher J, Pierpoint H, Beirne P, editors. The Palgrave International Handbook of Animal Abuse Studies. (2017) Pontypridd: Palgrave Macmillan. p. 15-38.

85. Dentinger CM, Jacob K, Lee L V., Mendez HA, Chotikanatis K, McDonough $\mathrm{PL}$, et al. Human Brucella canis infection and subsequent laboratory exposures associated with a puppy, New York City, 2012. Zoonoses Public Health. (2015) 62:407-14. doi: 10.1111/zph.12163

86. Nomura A, Imaoka K, Imanishi H, Shimizu H, Nagura F, Maeda K, et al. Human Brucella canis infections diagnosed by blood culture. Emerg Infect Dis. (2010) 16:1183-5. doi: 10.3201/eid1607.090209 
87. Sayan M, Erdenlig S, Stack J, Kiliç S, Güdücüoglu H, Aksoy Y, et al. A serological diagnostic survey for Brucella canis infection in Turkish patients with Brucellosis-like symptoms. Jpn J Infect Dis. (2011) 64:516-9.

88. Angel MO, Ristow P, Ko AI, Di-Lorenzo C. Serological trail of Brucella infection in an urban slum population in Brazil. J Infect Dev Ctries. (2013) 6:675-9. doi: 10.3855/jidc.2347

89. Marzetti S, Carranza C, Roncallo M, Escobar GI, Lucero NE. Recent trends in human Brucella canis infection. Comp Immunol Microbiol Infect Dis. (2013) 36:55-61. doi: 10.1016/j.cimid.2012.09.002

90. Polt SS, Dismukes WE, Flint A, Schaefer J. Human brucellosis caused by Brucella canis: clinical features and immune response. Ann Intern Med. (1982) 97:717-9. doi: 10.7326/0003-4819-97-5-717

91. Seimenis A, Tabbaa D. Stray animal populations and public health in the South Mediterranean and the Middle East regions. Vet Ital. (2014) 50:1316. doi: 10.12834/VetIt.48.134.3

92. Fatjó J, Bowen J, García E, Calvo P, Rueda S, Amblás S, et al. Epidemiology of dog and cat abandonment in Spain (2008-2013). Animals. (2015) 5:42641. doi: 10.3390/ani5020364

93. Peeler EJ, Reese RA, Thrush MA. Animal disease import risk analysis - a review of current methods and practice. Transbound Emerg Dis. (2015) 62:480-90. doi: 10.1111/tbed. 12180

94. Heesen S, Wendland B, Rach S, Rickert D. Hundeimporte aus süd- und osteuropa - hundehandel unter dem deckmantel des tierschutzes? -. Merkblatt Tierärztliche Vereinigung für Tierschutz eV. (2015) 2:1-21.

95. Wyatt T, Maher J, Biddle P. Scoping research on the sourcing of pet dogs from illegal importation and puppy farms 2016-2017. Agric Environ Mar Soc Res Ser. (2017) 4-92.

96. McMillan FD. Behavioral and psychological outcomes for dogs sold as puppies through pet stores and/or born in commercial breeding establishments: Current knowledge and putative causes. J Vet Behav Clin Appl Res. (2017) 19:14-26. doi: 10.1016/j.jveb.2017.01.001

Conflict of Interest Statement: FP was employed by company IDEXX Laboratories (Ludwigsburg, Germany).

The remaining authors declare that the research was conducted in the absence of any commercial or financial relationships that could be construed as a potential conflict of interest.

Copyright (c) 2019 Buhmann, Paul, Herbst, Melzer, Wolf, Hartmann and Fischer. This is an open-access article distributed under the terms of the Creative Commons Attribution License (CC BY). The use, distribution or reproduction in other forums is permitted, provided the original author(s) and the copyright owner(s) are credited and that the original publication in this journal is cited, in accordance with accepted academic practice. No use, distribution or reproduction is permitted which does not comply with these terms. 